\title{
Effects of Boerhavia diffusa L. nom. cons. and Chromolaena odorata (L.) R. M. King \& H. Rob. extracts on some field insect pests of okra (Aabelmoschus esculentus (L.) Moench)
}

\author{
Emmanuel T. NNEJI ${ }^{1,2}$, Robert O. UDDIN II ${ }^{1}$, Abdulrasak K. MUSA ${ }^{1}$
}

Received October 7, 2019; accepted January 20, 2020.

Delo je prispelo 7. oktobra 2019, sprejeto 20. januarja 2020.

Effects of Boerhavia diffusa L. nom. cons. and Chromolaena odorata (L.) R. M. King \& H. Rob. extracts on some field insect pests of okra (Aabelmoschus esculentus (L.) Moench)

Abstract: A field study was carried out to assess the efficacy of some botanicals in the control of field insect pests in two varieties of okra. Dry leaf extract of Chromolaena odorata (Siam weed) and fresh and dry root extracts of Boerhavia diffusa served as treatments which were compared with Lambdacyhalothrin and a control. The experiment was fitted into a randomized complete block design with three replications. Data collected were subjected to Spearman's correlation analysis and a two-way analysis of variance and significant different means were separated using Fishers Least Significant Difference (LSD) test at $5 \%$ level of probability. The results revealed that treated plants generally performed better than the untreated plants as they were taller, had more leaves, branches, wider stem girths and gave higher fruit yield. Fresh root extract of $B$. diffusa performed better in most parameters measured. A significant positive correlation was observed between insect pest populations, and between growth and yield parameters, while there was a significant negative correlation between overall yield and insect pest population. NHAe 47-4 okra variety performed better than F1-Lucky variety. Fresh root extract of $B$. diffusa is recommended for management of B. tabaci (Genadius, 1889) and Amrasca biguttula Ishida, 1912 in okra.

Key words: botanicals; Boerhavia diffusa; Chromolaena odorata; Bemisia tabaci; Amrasca biguttula; sticky traps
Učinki izvlečkov iz rastlin Boerhavia diffusa L. nom. cons. in Chromolaena odorata (L.) R.M. King \& H. Rob. na nekatere škodljive žuželke na jedilnem oslezu (Aabelmoschus esculentus (L.) Moench)

Izvleček: Za ocenitev učinkovitosti izvlečkov izbranih rastlin pri uravnavanju škodljivih žuželk na dveh sortah jedilnega osleza (okre, bamije) je bil izveden poljski poskus. Suhi listni izvlečki vrste Chromolaena odorata (L.) R.M. King \& H. Rob. in sveži ter suhi izvlečki korenin vrste Boerhavia diffusa L. nom. cons. so bili uporabljeni za obravnavanja v primerjavi $\mathrm{z}$ lamda cihalotrinom in kontrolo. Poskus je bil izveden kot popolni naključni bločni poskus s tremi ponovitvami. Zbrani podatki so bili analizirani s Spearmanovo korelacijo in dvosmerno analizo variance, značilno različna poprečja so bila ločena s Fisherjevim testom najmanjše značilne razlike (LSD) pri $5 \%$ verjetnosti. Rezultati so pokazali, da so tretirane rastline na splošno rastle bolje kot netretirane, bile so višje, imele so več listov in stranskih poganjkov, večji obseg stebla in večji pridelek plodov. Sveži izvlečki korenin vrste $B$. diffusa so se izkazali kot boljši v vseh merjenih parametrih. Opažena je bila značilno večja pozitivna korelacija med populacijami škodljivih žuželk in med parametri rasti in pridelka medtem, ko je bila korelacija med celokupnim pridelkom in populacijami škodljivih žuželk značilno negativna. Sorta okre NHAe 47-4 je uspevala bolje kot sorta F1-Lucky. Za uravnavanje tobakovega ščitkarja (B. tabaci (Genadius, 1889)) in vrste Amrasca biguttula Ishida, 1912 na jedilnem oslezu priporočamo izvlečke svežih korenin vrste $B$. diffusa.

Ključne besede: botanična sredstva za zatiranje škodljivcev; Boerhavia diffusa; Chromolaena odorata; Bemisia tabaci; Amrasca biguttula; lepljive pasti sticky traps

1 University of Ilorin, Faculty of Agriculture, Department of Crop Protection, Ilorin, Nigeria

2 Corresponding author, e-mail: emmanuelnneji@gmail.com 


\section{INTRODUCTION}

Okra, Abelmoschus esculentus (L.) Moench, is a commercially grown vegetable crop widely cultivated in Africa and Asia. Within 2009 and 2010, a global area of 0.43 million hectares was cultivated with total production standing at 4.54 million tons (Varmudy, 2011). India is the largest producer (67.1\%), with Nigeria following at (15.4\%) and Sudan (9.3\%) (Varmudy, 2011).

Okra plays a vital role in human diet (Kahlon et al. 2007, Saifullah and Rabbani 2009) providing phosphorus, calcium, sulphur, iron, fibre, fats, proteins, carbohydrates and vitamins (Lamont 1999, Owolarafe and Shotonde, 2004, Gopalan et al., 2007, Arapitsas 2008, Dilruba et al, 2009). Okra fruit is normally boiled in water to give slimy soup sauces that is relished. The seeds are nutritious, can be dried roasted and ground for use as additive or coffee substitute (Moekchantuk and Kumar 2004) while the fruits are also used to thicken soups and prepare vegetable curds.

In industries, mucilage from okra is often used to produce glace papers and confectioneries, also serving as a replacement for blood plasma as well as blood volume expander (Lengsfeld et al., 2004, Adetuyi et al., 2008, Kumar et al., 2010), it is also a useful remedy against genito-urinary problems, chronic dysentery and spermatorrhoea (Nadkarni, 1927). Okra has also been reported to cure ulcers and hemorrhoids (Adams, 1975). Results of tests conducted in China holds that alcoholic extracts from okra leaves have a potential to remove free radicals, reduce proteinuria, and generally improve renal functions (Liu et al., 2005, Kumar et al., 2009).

The cultivation of okra in Nigeria has indeed known success, however, it has also been greeted with a handful of constraints which include but may not be limited to insect pest infestations, disease incidence and poor soil nutrient level (Onunkun, 2012). In response to the constraints from insect pests, man has continued to search out eco-friendly strategies and methods for the management of these setbacks to okra production and agriculture in general (Praveen and Dhandapani, 2001). Some of these methods are; cultural, physical and biological control (Praveen and Dhandapani, 2001). Chemical control is also used and has become the most commonly used control method among farmers because of its almost immediate rate of success in the eradication of these insects, there has however been serious concerns about the long-term negative effect of continued or excessive use of synthetic formulations (Praveen and Dhandapani, 2001). More so, there is a serious need to enlighten farmers on safer, yet effective measures which are useful with almost no side effects or residual negative effects as those experienced while using chemicals. This study was therefore carried out to evaluate the effects of Boerhavia diffusa and Chromolaena odorata in control of insect pest infestations of two varieties of okra.

\section{MATERIALS AND METHODS}

\subsection{EXPERIMENTAL SITE}

The experimental site was located behind the Faculty of Agriculture greenhouse, University of llorin, Kwara State, Nigeria, located in the Southern Guinea Savannah agro-ecological zone of Nigeria, between Latitude $8^{\circ} 29^{\prime} \mathrm{N}$ and Longitude $4^{\circ} 35^{\prime} \mathrm{E}$. The experiment was carried out in 2018 cropping season. The climate of Ilorin includes rainy season which starts in April and ends in September while the dry season commences in October and ends in March. The dry spell is experienced in August of every year. The site has an average temperature of $35^{\circ} \mathrm{C}$ and is characterized by sandy loam soil.

\subsection{FIELD PREPARATION, AND LAYOUT OF EX- PERIMENTAL PLOT}

The land was cleared using cutlass and then mapped out into a plot size of $30 \mathrm{~m} \times 15 \mathrm{~m}$. Ridges were made at intervals of $50 \mathrm{~cm}$ spacing within plots. The field already mapped out for the experiment was set out using a Randomized Complete Block Design (RCBD). A spacing of $3 \mathrm{~m}$ was maintained between the two subplots of varieties, there were three replicates per treatment and $1 \mathrm{~m}$ was maintained between replicates, and $2 \mathrm{~m}$ from the boundaries of the plot. Each plot measured $2 \mathrm{~m} \times 3 \mathrm{~m}$ $\left(6 \mathrm{~m}^{2}\right)$ with three (3) ridges in each plot.

\subsection{OKRA VARIETIES AND PLANTING}

Two varieties of okra common to the farmers in Kwara State were used for the study, they are F1 Lucky and NHAe 47-4 varieties purchased from an Agro-input store in Ilorin. Seeds were planted at five (5) seeds per hole and $50 \mathrm{~cm}$ intra-row spacing on $6^{\text {th }}$ October 2018. Two weeks after emergence, thinning was carried out leaving two plants per stand. There were 24 plants in each plot.

\subsection{TREATMENTS, PREPARATION, AND APPLI- CATION}

Treatments used for the study were; ethanol leaf 
extracts of Siam weed, Chromolaena odorata (L.) R.M. King \& H. Rob. ethanol extracts of fresh and dried Red Spiderling, Boerhavia diffusa L. nom. cons. Laraforce - (a.i. lambda-cyhalothrin) as standard check; and untreated control. Chromolaena odorata leaf and B. diffusa root were sourced from the forest of University of Ilorin. These plant parts were harvested and air dried in the shade for three (3) weeks, the roots were crushed using mortar and pestle while the leaves were ground using a kitchen size electric blender. They were further sieved using a sieve of $2 \mathrm{~mm}$ mesh to obtain a uniform powder.

Plant extracts were prepared by maceration. $50 \mathrm{~g}$ of each powder were measured into $400 \mathrm{ml}$ of $90 \%$ ethanol and allowed to stand for twenty-four hours while shaking from time to time to ease extraction. The resulting suspension was filtered using muslin cloth, and the filtrate was made up to 2 litres (1:40 or $2.5 \% \mathrm{w} / \mathrm{v}$ ratio) by adding distilled water, $2 \mathrm{ml}$ of liquid soap per litre of solution was used as surfactant (Anjarwalla, 2016). Lambdacyhalothrin $2.5 \%$ emulsifiable concentrate was used as a standard check at $0.5 \mathrm{~g}$ per litre.

Treatment application commenced four (4) weeks after planting and was done at one-week interval to the $7^{\text {th }}$ week after planting (WAP).

\subsection{CULTURAL PRACTICES}

Plots were weeded using hoe at 3 WAP (Adigun, 2005). Selective spraying using herbicide (Glyphosate) was done at 6 WAP at the recommended rate.

\subsection{INSTALLATION OF YELLOW STICKY TRAPS}

One (1) yellow sticky trap was installed per plot, they were placed at the center of the plots at 4 WAP. They were $50 \mathrm{~cm}$ above the ground and were left on the plots for two weeks after which they were collected and taken to the Crop Protection Department Laboratory for insect identification and counting. Insects identified include whiteflies (Homoptera) and leafhoppers (Hemiptera). Physical counting was done using hand lens of $10 \mathrm{x}$ magnification and Gordon's dichotomous key to the order of insects (Gordon, 2019) as aid.

\subsection{DATA COLLECTION}

Five plants per plot were selected at random and tagged. Collection of data commenced at 5 WAP and continued at a week interval to fruiting and harvest. Data were collected on plant height, number of branches, whitefly and leafhopper population, number of days to flowering, number of fruits, and mass of fruits.

\subsection{DATA ANALYSIS}

Data collected were subjected to a two-way analysis of variance (ANOVA) and Spearman's Correlation Analysis using Genstat $17^{\text {th }}$ edition, and significantly different means were separated using Fishers Least Significant Difference (LSD) test at $5 \%$ level of significance.

\section{RESULTS AND DISCUSSION}

The results of the study revealed that the various treatments used in the experiment had significant effects on both growth and yield parameters of F1-Lucky and NHAe 47-4 varieties of okra. Plants treated with fresh root extracts of $B$. diffusa generally performed better than untreated plants. The treated plots produced plants which were taller and had more branches compared to those of untreated plots (Tables 1 and 2). This may be because treated plants suffered less infestation from whitefly (Bemisia tabaci (Gennadius, 1889) and leafhopper (Amrasca biguttula Ishida, 1912) compared to untreated plots (Table 4). This corroborates the findings of Bindhu et al. (2015) who reported that B. diffusa and some other plants contained various compounds which are known to have repellent and toxic effects on insects. It also confirms the reports from several studies which have shown C. odorata to have pesticidal properties, among these reports are Owolabi et al. (2010) who reported that C. odorata has been used to manage Sitophilus zeamais (Motschulsky), 1855 which belongs to the order (Coleoptera). Studies have revealed that B. diffusa and C. odorata contain phytochemicals that are effective in insect pest control (Afolabi et al., 2007 and Deepti et al., 2013).

The better growth performance recorded in treated plants may also be because the plants had lesser infection from diseases vectored by the insect pests identified during the study. Okra is susceptible to at least nineteen plant viruses (Brunt et al., 1990; Swanson and Harrison, 1993). These viruses seriously affect its growth and yield. In several parts of Africa, okra leaf curl disease (OLCD) is considered to be the most serious disease threatening okra production (N'Guessan et al., 1992; Swanson and Harrison, 1993; Bigarré et al., 2001). OLCD is transmitted by whitefly (Bemisia tabaci). The incidence and abundance of whiteflies will always be directly proportional to the incidence and severity of OLCD (Bigarré et al., 2001). Therefore, the treated plants facing lesser infestation of whiteflies may have also had lesser incidence of 
Table 1: Main effect of treatments and variety on the plant height of okra

\begin{tabular}{|c|c|c|c|c|c|}
\hline \multirow[b]{2}{*}{ Treatments } & \multicolumn{5}{|c|}{$\begin{array}{l}\text { Plant height }(\mathrm{cm}) \\
\text { WAP }\end{array}$} \\
\hline & 5 & 6 & 7 & 8 & 9 \\
\hline Fresh Root extract of $B$. diffusa & 25.29 & 39.92 & $54.53^{\mathrm{a}}$ & $59.70^{\mathrm{a}}$ & $70.70^{\mathrm{a}}$ \\
\hline Dry root extract of $B$. diffusa & 23.15 & 35.33 & $47.83^{\mathrm{ab}}$ & $55.75^{\mathrm{ab}}$ & $62.71^{\mathrm{ab}}$ \\
\hline Dry leaf extract of C. odorata & 20.74 & 28.61 & $38.00^{\mathrm{b}}$ & $43.68^{\mathrm{ab}}$ & $49.10^{\mathrm{b}}$ \\
\hline Lambda-cyhalothrin & 21.82 & 31.66 & $41.22^{\mathrm{ab}}$ & $47.14^{\mathrm{ab}}$ & $53.76^{\mathrm{ab}}$ \\
\hline Control & 19.90 & 28.47 & $36.79^{\mathrm{b}}$ & $41.33^{\mathrm{b}}$ & $46.47^{\mathrm{b}}$ \\
\hline SEM & 2.67 & 4.39 & 5.47 & 6.00 & 7.07 \\
\hline LSD & 7.81 & 12.84 & 15.99 & 17.57 & 20.69 \\
\hline \multicolumn{6}{|l|}{ Variety } \\
\hline F1-Lucky (kousko) & $18.55^{\mathrm{b}}$ & $28.40^{\mathrm{b}}$ & 39.10 & 45.00 & 51.50 \\
\hline NHAe $47-4$ & $25.81^{\mathrm{a}}$ & $37.10^{\mathrm{a}}$ & 48.20 & 54.00 & 61.50 \\
\hline SEM & 1.34 & 2.61 & 3.52 & 3.88 & 4.69 \\
\hline LSD & 3.88 & 7.59 & 10.22 & 11.27 & 13.63 \\
\hline
\end{tabular}

Values in the same column followed by the same letter(s) are not significantly different at $\mathrm{p}=0.05$ according to Fisher's protected Least Significant Difference (LSD) Test

Key: WAP: Weeks after Planting

Table 2: Main effect of treatments and variety on number of branches of okra

\begin{tabular}{|c|c|c|c|c|}
\hline \multirow[b]{2}{*}{ Treatments } & \multicolumn{4}{|c|}{ Number of branches (WAP) } \\
\hline & 6 & 7 & 8 & 9 \\
\hline Fresh root extract of $B$. diffusa & $4.18^{\mathrm{a}}$ & $5.43^{\mathrm{a}}$ & $6.48^{\mathrm{a}}$ & $7.48^{\mathrm{a}}$ \\
\hline Dry root extract of $B$. diffusa & $3.02^{\mathrm{b}}$ & $4.27^{\mathrm{b}}$ & $5.24^{\mathrm{b}}$ & $6.24^{\mathrm{b}}$ \\
\hline Dry leaf extract of C. odorata & $2.28^{\mathrm{b}}$ & $3.53^{\mathrm{b}}$ & $4.96^{\mathrm{b}}$ & $5.96^{\mathrm{b}}$ \\
\hline Lambda-cyhalothrin & $3.35^{\mathrm{ab}}$ & $4.60^{\mathrm{ab}}$ & $5.40^{\mathrm{ab}}$ & $6.40^{\mathrm{ab}}$ \\
\hline Control & $2.75^{\mathrm{b}}$ & $4.00^{\mathrm{b}}$ & $4.48^{\mathrm{b}}$ & $5.48^{\mathrm{b}}$ \\
\hline SEM & 0.50 & 0.50 & 0.50 & 0.50 \\
\hline LSD & 1.10 & 1.10 & 1.10 & 0.70 \\
\hline \multicolumn{5}{|l|}{ Variety } \\
\hline F1-Lucky (kousko) & $2.00^{\mathrm{b}}$ & $4.00^{\mathrm{b}}$ & $5.00^{\mathrm{b}}$ & $6.00^{\mathrm{b}}$ \\
\hline NHAe $47-4$ & $4.00^{\mathrm{a}}$ & $5.00^{\mathrm{a}}$ & $6.00^{\mathrm{a}}$ & $7.00^{\mathrm{a}}$ \\
\hline SEM & 0.30 & 0.30 & 0.30 & 0.30 \\
\hline LSD & 0.70 & 0.70 & 0.70 & 0.70 \\
\hline
\end{tabular}

Values in the same column followed by the same letter(s) are not significantly different at $\mathrm{p}=0.05$ according to Fisher's protected Least Significant Difference (LSD) Test

Key: WAP: Weeks after Planting

Okra Leaf Curl Virus which translated to better growth and yield (Table 6). Fidèle (2010) reported a significant decrease in plant height and some other yield-contributing parameters in four accessions of okra which had symptoms of OLCD.

The NHAe 47-4 variety flowered earlier than the F1Lucky variety (Table 3). Furthermore, treated plants in the plots for fresh root extracts of $B$. diffusa gave higher fruit yield in both varieties studied (Table 6). This may be because treated plants which were less infested were able to carry out photosynthesis without disruption. Edward and Abdelaziz (2007) reported that any impairment of photosynthetic efficiency by insect pests such as leafhoppers is irreversible and hopper-burn affects plant biomass 
Table 3: Main effect of treatments and variety on days to flowering of okra

\begin{tabular}{ll}
\hline Treatment & Days to flowering \\
\hline Fresh root extract of B. diffusa & 45.76 \\
Dry root extract of B. diffusa & 46.37 \\
Dry leaf extract of C. odorata & 46.97 \\
Lambda-cyhalothrin & 48.07 \\
Control & 48.70 \\
SEM & 1.69 \\
LSD & 4.17 \\
\hline Variety & \\
\hline F1-Lucky (kousko) & $49.38^{\mathrm{b}}$ \\
NHAe 47-4 & $44.96^{\mathrm{a}}$ \\
SEM & 0.85 \\
LSD & 5.90 \\
\hline
\end{tabular}

Values followed by the same letter(s) are not significantly different at $\mathrm{p}=$ 0.05 according to Fisher's protected Least Significant Difference (LSD)

Table 4: Main effect of treatments and variety on the population of adult whitefly and leafhopper per yellow sticky trap

\begin{tabular}{lll}
\hline Treatment & $\begin{array}{l}\text { Whitefly } \\
\text { population }\end{array}$ & $\begin{array}{l}\text { Leafhopper } \\
\text { population }\end{array}$ \\
\hline Fresh root extract of $B$. diffusa & $298.20^{\mathrm{b}}$ & $2.33^{\mathrm{a}}$ \\
Dry root extract of $B$. diffusa & $404.20^{\mathrm{d}}$ & $9.00^{\mathrm{d}}$ \\
Dry leaf extract of C. odorata & $289.30^{\mathrm{a}}$ & $5.00^{\mathrm{b}}$ \\
Lambda-cyhalothrin & $301.50^{\mathrm{c}}$ & $5.50^{\mathrm{bc}}$ \\
Control & $653.30^{\mathrm{e}}$ & $7.00^{\mathrm{c}}$ \\
SEM & 1.12 & 0.66 \\
LSD & 3.32 & 1.96 \\
\hline Variety & & \\
\hline F1-Lucky (kousko) & $416.00^{\mathrm{b}}$ & 6.00 \\
NHAe 47-4 & $363.00^{\mathrm{a}}$ & 5.53 \\
SEM & 0.71 & 0.42 \\
LSD & 2.10 & 1.24 \\
\hline
\end{tabular}

Values in the same column followed by the same letter(s) are not significantly different at $\mathrm{p}=0.05$ according to Fisher's protected Least Significant Difference (LSD) Test

accumulation by reducing green leaf area and efficiency of solar radiation capture. Aishwarya (2018) also submitted that both nymph and adults cause damage to okra by sucking the cell sap from the lower surface of leaf, twigs and other tender parts of the plant, causing curling of leaves and leading to stunted growth of the plants. They further reported that leafhoppers excrete honey dew which causes the black sooty mold which has an adverse effect on the photosynthetic ability of the plants. Several reports including Kedar et al. (2014) and Aishwarya Ray (2018) have revealed that whiteflies and their nymphs suck cell sap from plant leaves and affected leaves curl and dry with the affected plants showing a stunted growth. Whiteflies are also responsible for transmitting yellow vein mosaic virus (YVMV), an economically important disease of okra, the symptoms being interwoven networks of yellow veins surrounded by islands of green tissues on the leaves which also turn yellow with time (Kedar et al., 2014; Aishwarya, 2018). The control of incidence of these insect pests and the consequent reduction or elimination of the occurrence of diseases mediated by the insect pests identified on the plots may have translated to the better yield obtained from the treated plots.

The study also revealed a strong positive correlation exists between leafhopper and whitefly population, plant height and number of fruits, plant height and overall yield, and number of fruits and overall yield (Table 5). This suggests that the leafhopper population increased with the whitefly population, while the yield was directly proportional to the growth of the plants.

\section{CONCLUSION}

The findings of this study revealed that ethanol extracts of Boerhavia diffusa and Chromolaena odorata had significant positive effects on growth and yield of okra and were also effective in reducing the population of leafhoppers and whiteflies in treated plots. There was a significant positive correlation between leafhopper and whitefly population, plant height and number of fruits, plant height and overall yield, and number of fruits and overall yield. While there was a significant negative correlation between overall yield and whitefly population. There was a non-significant negative correlation between whitefly population and plant height, whitefly population and number of fruits, leafhopper population and plant height, leafhopper population and number of fruits, and leafhopper population and overall yield.

Of the two botanicals evaluated fresh root extract of B. diffusa on NHAe 47-4 okra variety performed better than other treatments from germination and emergence, through growth parameters to yield.

\section{REFERENCES}

Adams, C. F. (1975). Nutritive value of American foods in common units, U.S. Department of Agriculture, Agric Handbook. 425-29.

Adetuyi, F.O., Osagie, A.U. and Adekunle, A. T. (2008). Effects of postharvest storage techniques on the nutritional prop- 
Table 5: Spearman's correlation matrix for various parameters in the study

\begin{tabular}{lllll}
\hline & Whitefly population & Leafhopper population & Plant height & Number of fruits/ha \\
\hline Leafhopper population & $0.469^{* *}$ & & & \\
Plant height & -0.287 & -0.191 & $0.688^{* *}$ & $0.966^{* *}$ \\
Number of fruits/ha & -0.249 & -0.117 & $0.746^{* *}$ & 0.215 \\
Overall yield $\left(\mathrm{kg} \mathrm{ha}^{-1}\right)$ & $-0.364^{\star}$ & -0.15 & \\
\hline
\end{tabular}

**. Correlation is significant at the 0.01 level (2-tailed).

*. Correlation is significant at the 0.05 level (2-tailed).

Table 6: Main effect of treatments and variety on number of fruits per plant, number of fruits per plot, and overall yield (kg ha-1) of okra

\begin{tabular}{llll}
\hline Treatments & Number of fruits/plant & Number of fruits/plot & Fruit yield (kg ha- ${ }^{-1}$ \\
\hline Fresh root extract of B. diffusa & 13.76 & 165.10 & $2029.00^{\mathrm{a}}$ \\
Dry root extract of B. diffusa & 9.48 & 113.80 & $1231.00^{\mathrm{ab}}$ \\
Dry leaf extract of C. odorata & 9.50 & 114.10 & $1304.00^{\mathrm{ab}}$ \\
Lambda-cyhalothrin & 8.81 & 106.10 & $1223.00^{\mathrm{ab}}$ \\
Control & 7.66 & 91.20 & $980.00^{\mathrm{b}}$ \\
SEM & 2.20 & 26.30 & 334.20 \\
LSD & 6.40 & 76.90 & 977.60 \\
\hline Variety & & & $878.00^{\mathrm{b}}$ \\
\hline F1-Lucky (kousko) & $7.00^{\mathrm{b}}$ & $80.00^{\mathrm{b}}$ & $1829.00^{\mathrm{a}}$ \\
NHAe 47-4 & $13.00^{\mathrm{a}}$ & $155.90^{\mathrm{a}}$ & 178.30 \\
SEM & 1.10 & 13.50 & 518.40 \\
LSD & 3.30 & 39.25 & \\
\hline
\end{tabular}

Values in the same column followed by the same letter(s) are not significantly different at $\mathrm{p}=0.05$ according to Fisher's protected Least Significant Difference (LSD) Test

erties of Benin indigenous Okra Abelmoschus esculentus (L.) Moench). Pakistan Journal of Nutrition, 7, 652-657. https://doi.org/10.3923/pjn.2008.652.657

Adigun, J.A. (2005). Critical period of weed interference in rain-fed and irrigated tomatoes in the Nigerian savanna, Journal of Agricultural Research and Development, 2, 32-41. https://doi.org/10.4314/jard.v2i1.42197

Afolabi, C., Akinmoladun, E.O., Ibukun and I.A. Dan-Ologe (2007). Phytochemical constituents and antioxidant properties of extracts from the leaves of Chromolaena odorata. Scientific Research and Essay, 2(6), 191-194. Available online at http://www.academicjournals.org/SRE ISSN 19922248 (c) 2007 Academic Journals

Aishwarya Ray (2018). Studies on insect-pests of okra (Abelmoschus esculentus) with special reference to seasonal incidence and bio-rational management of okra shoot and fruit borer (Earias spp.), unpublished thesis; $92 \mathrm{pp.}$

Anjarwalla, P., Belmain, S., Ofori, D.A., Sola, P., Jamnadass, R., Stevenson, P.C. (2016). Handbook on Pesticidal Plants. World Agroforestry Centre (ICRAF), Nairobi, Kenya.

Arapitsas, P. (2008). Identification and quantification of polyphenolic compounds from okra seeds and skins. Food Chemistry, 110, 1041-1045. https://doi.org/10.1016/j.foodchem.2008.03.014
Bigarré, L., Chazly, M., Salah, M., Ibrahim, M., Padidam, M., Nicole, M., Peterschmitt, M., Fauquet, C., Thouvenel, J.C. (2001). Characterization of a new Begomo virus from Egypt infecting hollyhock (Althea rosea). European Journal of Plant Pathology, 107, 701-711. https:/doi. org/10.1023/A:1011967232319

Bindhu, V.R., Ganga, S., Dayanandan, S. (2015). Mortality effects of some medicinal plants on the pulse beetle Callosobruchus chinensis (Coleoptera: Bruchidae). Journal of Fertilizer \& Pesticides, 6, 150. https://doi.org/10.4172/21556202.1000150

Brunt, A., Crabtree, K., Gibbs, A. (1990). Viruses of Tropical Plants. CAB International, Wallingford, UK.

Deepti Malhotra, Amir Khan and Fouzia Ishaq (2013). Phytochemical screening and antibacterial effect of root extract of Boerhavia diffusa L. (Family Nyctaginaceae). Journal of Applied and Natural Science, 5(1), 221-225. https://doi. org/10.31018/jans.v5i1.310

Dilruba, S., Hasanuzzaman, M., Karim, R., Nahar, K. (2009). Yield response of okra to different sowing time and application of growth hormones. Journal of Horticultural Science. Ornamental Plants, 1, 10-14.

Edward, B. Radcliffe, Abdelaziz Lagnaoui (2007). Potato Biology and Biotechnology. 
Fidèle Tiendrébéogo, V.S. Edgar Traoré, Jean-Michel Lett, Nicolas Barro, Gnissa Konaté, Alfred S. Traoré, Oumar Traoré (2010). Impact of okra leaf curl disease on morphology and yield of okra. Crop Protection, 29. (2010)712e716. https://doi.org/10.1016/j.cropro.2010.02.007

Gopalan, C., Sastri, S. B. V., Balasubramanian, S. (2007). Nutritive value of Indian foods, National Institute of Nutrition (NIN), ICMR, India. P1.

Gordon Ramel (2019). Key to the Identification of Insects to Order, A Few Words About KEYS, Adapted from Harold Oldroyd 1958. https://www.earthlife.net/insects/orders-key. html\#key

Kedar, S. C., K. M. Kumaranag, D. S., Bhujbal and N. H. Thodsare4 (2014). Insect Pests of Okra and Their Management. Popular Kheti, 2(3), 112-119.

Kumar, R., Patil, M. B., Patil, S. R., Paschapur, M. S. (2009). Evaluation of Abelmoschus esculentus mucilage as suspending agent in paracetamol suspension. International Journal of Pharmaceutical and Technology Research, 1, 658-665.

Lamont, W. (1999). Okra a versatile vegetable crop. Horticultural Technology; 9: 179-184. Lee K, Cho CY, Park SK (1990). The effect of nitrogen fertilizer, plant density and sowing date on the yield of okra. Korean Journal of Crop Science, 35(8), 179-183. https://doi.org/10.21273/HORTTECH.9.2.179

Lengsfeld, C., Titgemeyer, F., Faller, G., Hensel, A. (2004). Glycosylated compounds from okra inhibit adhesion of Helicobacter pylori to human gastric mucosa. Journal of Agriculture and Food Chemistry, 52, 1495-1503. https://doi. org/10.1021/jf030666n

Liu, I. M., Liou, S. S., Lan, T. W., Hsu, F. L., Cheng, J. T. (2005). Myricetin as the active principle of Abelmoschus moschatus to lower plasma glucose in streptozotocin-induced diabetic rats. Planta Medica, 71, 617-621. https://doi. org/10.1055/s-2005-871266

Moekchantuk, T., Kumar, P. (2004). Export okra production in Thailand. Inter-country programme for vegetable IPM in South and SE Asia phase II Food and Agriculture Organization of the United Nations, Bangkok, Thailand. P1.

Nadkarni, K. M. (1927). Indian Meteria Medica. Nadkarni and Co Bombay. P1.

N'Guessan, K.P., Fargette, D., Fauquet, C., Thouvene, L.J.C. (1992). Aspects of the epidemiology of okra leaf curl virus in Côte d'Ivoire. Tropical Pest Management, 38, 122-126. https://doi.org/10.1080/09670879209371668

Onunkun, O. (2012). Evaluation of aqueous extracts of five plants in the control of flea beetles on okra (Abelmoschus esculentus (L.) Moench). JBiopest, 5(supplementary), 62-67.

Owolarafe, O. K., Shotonde, H. O. (2004). Some physical properties of fresh okra fruit. Journal of Food Engineering, 63, 299-302. Journal of the Ghana Science Association, 3(3), 136-144. https://doi.org/10.1016/j.jfoodeng.2003.08.002

Praveen, P.M., \& N. Dhandapani (2001). Eco-rriendly management of major pests of okra (, (L.) Moench), Journal of Vegetable Crop Production, 7(2), 3-12. https://doi.org/10.1300/ J068v07n02_02

Saifullah, M., Rabbani, M. G. (2009). Evaluation and characterization of okra (Abelmoschus esculentus L. Moench.) genotypes. SAARC Journal of Agriculture, 7, 92-99.

Swanson, M.M., Harrison, B.D. (1993). Serological relationships and epitope profiles of isolates of okra leaf curl geminivirus from Africa and the Middle-East. Bio-chimie, 75, 707-711. https://doi.org/10.1016/0300-9084(93)90101-W

Varmudy, V. (2011). Marketing Survey needed to boost okra exports. Department of economic Vive Kananda College, Puttur Karnataka. P1. 